\title{
Soil Erosion Estimation and Watershed Prioritization in Kulfo Watershed, Ethiopia
}

\author{
Anmut Enawgaw Kassie* \\ Department of Natural Resources Management, Debre Markos University Burie Campus, \\ Ethiopia; P.O Box: 18 \\ Dessie Gieta Amare* \\ Department of Natural Resources Management, Debre Markos University Main Campus, \\ Ethiopia; P.O Box: 269 \\ Guchie Gullie Sulla \\ Department of Water Resources and Irrigation Engineering, \\ Arbaminch University, Ethiopia; P.O Box: 21
}

\begin{abstract}
Soil loss by runoff is a severe and continuous environmental and infrastructural problem in Kulfo watershed. Deforestation and improper cultivation have resulted in accelerated soil erosion. Information on soil loss is essential to support agricultural productivity and watershed management. Thus, study was aimed to estimate and map the soil loss by using GIS and RUSLE techniques raster format in GIS environment. Topographic map of 1:250,000 scale. Aster Digital Elevation Model (DEM) of $30 \mathrm{~m}$ spatial resolution. Digital soil map of 1:250.000 scales, fifteen years rainfall records of six stations nearby watershed and land sat imagery (ETM+) with spatial resolution of $30 \mathrm{~m}$ were used to derive RUSLE's soil loss parameter. The RUSLE parameters were analyzed and superimposed using raster calculator in the geo-processing tools in ArcGIS10.2 environment to estimate and map the annual soil loss of the study area. The result showed that the mean annual soil loss of the watershed range from none significant $\left(0\right.$ tons $\left.\mathrm{ha}^{-1} \mathrm{y}^{-1}\right)$ to highly sever $\left(253.38\right.$ ton $\left.\mathrm{ha}^{-1} \mathrm{y}^{-1}\right)$. The mean annual soil loss of the whole watershed was 88.57 tons ha $^{-1} \mathrm{y}^{-1}$. The total annual soil loss in the watershed was 3,862,077 ton per year from 39900 ha of land. The soil erosion affected is spatially situated in the upper steepest slope part and middle part of the watershed. This area where acrisols with high soil Erodibility character are dominant Hence, Slope gradient and length followed by soil Erodibility factors were found to be the main factors of soil erosion .The morphological character also the determinant factor for soil and water conservation practice. Thus, sustainable soil and water conservation practices should be adopted in the most sever area of the watershed.
\end{abstract}

Keywords: Geographical Information System, Erosion, RUSLE, watershed prioritization

DOI: $10.7176 / J N S R / 10-1-01$

Publication date: January $31^{\text {st }} 2020$

\section{Introduction}

Soil is the top layer of the earth's crust that is capable of sustaining life. It is very important to farmers, who depend on it to provide abundant and healthy crops each year. One major problem in agriculture is soil erosion. Soil erosion is the detachment, transportation and deposition of soil particles from a given site to another. Wind, water, ice, animals and the use of tools by manure usually the main agents of soil erosion. It is a natural process which usually does not cause any major problems unless accelerated by human activities. It becomes a difficulty when human activity causes it to occur much faster than under ordinary conditions. Water is the most important erosion agent and erodes most commonly as running water over land or in streams. Soil erosion is one of the most serious environmental and public health problems facing human society in the world. The loss of soil from land surface by erosion is wide spread and adversely affecting the productivity of natural ecosystem as well as agricultural lands. Soil is a limited strategic resource of huge social, economic and environmental significance. However, the use of inappropriate farming methods can lead to erosion and limit the productive capacity of the soil (Lal, 2001). Soil erosion by water occurs in various forms (for instance: splash, sheet, rill, gullies) depending on the stage of progress in the erosion cycle and the position in the landscape. Inappropriate crop farming and animal husbandry practice in Kulfo watershed has led excessive soil erosion in some parts and pollution of Chamo Lake at downstream of the watershed. The environmental problems that were developed in Kulfo watershed include lake sedimentation, depletion of biodiversity and loss of land productivity. Hence, the study of soil erosion in Kulfo watershed is required for planning sustainable management of land resource and water resource development. To investigate soil erosion variations using the spatially variable factors that affect the erosion processes, recent developments of global observation by remote sensing are helpful. The study aimed to quantify soil loss and classify the watershed on the basis of soil erosion severity in the watershed using Revised Universal Soil Loss Equation (RUSLE) and Geographic Information System (GIS). Using spatial distribution of vegetation 
cover, soil and digital elevation model (DEM), it is possible to extract topographical, soil and crop parameters of soil erosion. Based on the (FAO-UNESCO) global digital soil map (FAO, 1985), the global data set of soil properties has been made available by the Data and Information System (DIS) frame work activity of the International Geosphere-Biosphere Programmer (IGBP) (Scholes et al.,1995).

\section{Materials and Methods}

\subsection{Description of the Study Area}

The study area which is Kulfo watershed is geographically found between $37^{0} 28^{\prime} 00.94^{\prime \prime}$ and $37^{0} 34^{\prime} 03.34^{\prime \prime E a s t}$ longitude and $6^{0} 03^{\prime} 49.19$ " and $6^{0} 03^{\prime} 11.71$ " North latitude. Kulfo watershed is one of the watersheds in Abaya Chamo Lakes basin in Rift Valley Lakes basin. The watershed drains to Chamo Lake in the basin. The maximum and minimum elevation of the watershed is 3557 and $1192 \mathrm{~m}$ a.m.s.l. respectively.
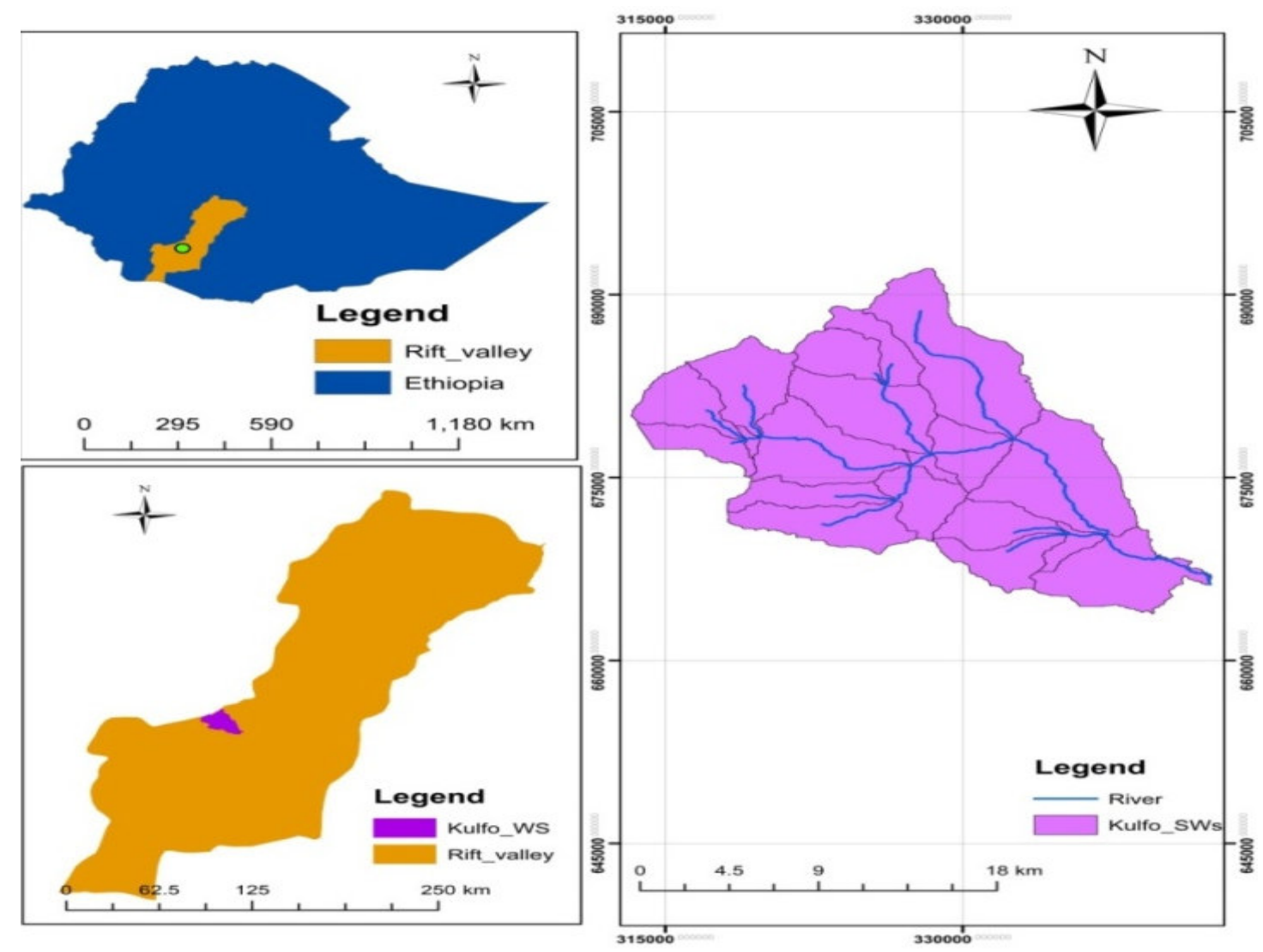

Figure 1: Location of Kulfo watershed

\subsection{Models and Software Used for soil loss estimation and Sub Watershed Prioritization}

In this study, Revised Universal Soil Loss Equation ( RUSLE) was used to estimate the average annual soil loss which is expressed as mass per unit are a per year (tone $h^{-1} \mathrm{y}^{-1}$ ). The RUSLE was applied in ArcGIS 10.2environment to determine the average annual soil loss. Parameter values of RUSLE soil erosion factors were generated in ArcGIS 10.2. Land use/cover classification has been carried out using ERDAS Imagine software from 2011 Landsat Satellite image.

\subsubsection{Description of Revised Universal Soil Loss Equation}

The Revised Universal Soil Loss Equation (RUSLE) is an empirically based model that has the ability to predict the long term average annual rate of soil erosion on a field slope as a result of rainfall distribution, soil type, topography, crop system and management practices of the catchment (Renard et al., 1997). The RUSLE model in GIS environment can predict erosion potential on a cell-by-cell basis which is, effective when attempting to identify the spatial pattern of soil loss present within a large watershed area (Shi et al., 2003). Despite this advantage, RUSLE does not estimate sediment deposition and gully erosion. RUSLE computes average annual erosion as a function of six factors (Renard.et al., 1997):

$\mathrm{A}=\mathrm{R} * \mathrm{~K} * \mathrm{~L} * \mathrm{~S} * \mathrm{C} * \mathrm{P}$

Where: $\mathrm{A}=$ computed average annual soil loss in tons/hectare/year, $\mathrm{R}=$ rainfall-runoff Erosivity factor $(\mathrm{mm}), \mathrm{K}$ $=$ soil Erodibility factor (unit less), $\mathrm{L}=$ slope length factor $(\mathrm{m}), \mathrm{S}=$ slope steepness factor $(\%), \mathrm{C}=$ cover management factor (unit less), and $\mathrm{P}=$ conservation practice factor (unit less) 


\subsubsection{Generation of Parameter values of RUSLE soil erosion factors 2.2.2.1 Rainfall Factor ( $R$ factor)}

Rainfall Erosivity factor is defined as the capability of rainfall to cause erosion and given as the product of the total energy of rainstorm (E) and the maximum 30-min intensity (I 30) (Wischmeier\& Smith, 1958). The rainstorm (E) and intensity (I) is a statistical interaction term that reflects how total energy and peak intensity are combined in every particular storm. The Erosivity factor $\mathrm{R}$ was calculated according to the equation given by Hurni (1985), derived from a spatial regression analysis (Hellden, 1987) for Ethiopian conditions based on the easily available mean annual rainfall $(\mathrm{P})$. It is given by a regression equation:

$\mathrm{R}=-8.12+0.562 * \mathrm{P}$

\subsubsection{Soil Erodibility Factor (K factor)}

The soil data forth is study was obtained from digital soil map of Ministry of Agriculture and Natural Resources (MoANR) with the scale of 1:25000.000. The soil map has a polygon shape format. The soil feature map of the study area was obtained by clipping from the soil map of MoANR for the study watershed in the GIS environment. Then, the Erodibility value of K-factor was assigned for each of the three soil category based on their characteristics as indicated by $(\mathbf{F A O}, \mathbf{1 9 8 4})$. The vector soil map w a s converted to raster format using spatial analysis tool in Arc-Info10.2 and then the value field of the soil layer was reclassified by the respective value of K-factor, using reclassify tool of spatial analyst extension in Arc-Info10.2 a n d subsequently raster layer of $\mathrm{K}$-factor was generated.

\subsubsection{Terrain Factor (LS_factor)}

The terrain factor includes both slope length and slope steepness effects on soil loss. The quantity of erosion increases as the slope length of the watershed increases (Wischmeier and Smith, 1978). Slope length is the distance along the flow path from the origin of overland flow to the point where deposition occurs Factors were calculated together in one formula indicated below:

$\mathrm{LS}=\left(\lambda^{0.3 / 22.1)} *(\mathrm{~S} / 9)\right.$

Where: $\lambda=$ Flow length $(\mathrm{m})$, and $\mathrm{S}=$ Slope in percent $(\%)$

\subsubsection{Cover Management Factor (C-Factor)}

Assessment of the type of land use/cover was made separately for each land unit and the corresponding value for land use/cover was obtained from Hurni (1985) which was adapted to Ethiopian condition. Inorder to determine C-factor of Kulfo watershed land use land cover was classified into six land use classes from Landsat image acquired in 2011 by applying maximum likelihood of supervised classification. Land use land cover data was generated by ERDAS Imagine software from the satellite image using supervised classification. The 2011 land sat satellite image was used to classify the current land use/cover of the watershed. The image has $30 * 30$ meter resolution. Ground truth data was used for the supervised image classification. Accuracy assessment and validation of the result the selection of appropriate time for ground truth data collection was fundamental issue. Hence, the ground truth data was required to be collected for similar period of the image acquisition. Having this in mind field data collection was done from June 1 to $8 / 2016$. The materials used during field data collection were supervised classification of land use land cover map of 2011 GARMIN GPS and Digital Camera. Data collection was done through site selection of known point both on the ground and on the map. The land use land cover information and coordinate values have been recorded. To minimize the expected possible error from GPS the reading and comparisons have been taken by moving into the center of the land use/cover rather than taking the reading from the edge, with the help of visual interpretation elements and the different reflection characteristics of the features in the satellite image. The study area was classified into five land use/cover classes. Namely cultivated land, forest, urban, shrub land and riparian vegetation after getting the classified image the raster format was changed into vector format and the corresponding C-value which was obtained from Hurni (1985) was assigned and $\mathrm{C}$ - factor map was produced in the form of raster.

To assess the accuracy of the LULC classification, field data was compared against the classified images. For each of the classified cover, types random sample points were established. Then each random sample point visited in the field and the actual cover type has been verified (recorded as reference data). The overall classification accuracy was computed as the ratio of total number of correct class predictions (the sum of the diagonal cells) divided by the total number of cells. In this study, the overall classification accuracy was found to be equal to 94 percent (Table 2) with Kappa coefficient of 92 percent.

$$
\text { Accuracy }=\frac{\text { Sum of the diagonal }}{\text { Sum of tota }} * 100
$$


Table 1: The accuracy assessment and kappa coefficient of image classification

\begin{tabular}{|c|c|c|c|c|c|c|c|}
\hline Class name & $\mathrm{F}$ & $\mathrm{IC}$ & $\mathrm{MC}$ & RV & ShL & $\mathrm{U}$ & Row total \\
\hline $\mathrm{F}$ & 9 & 0 & 0 & 2 & 3 & 0 & 14 \\
\hline $\mathrm{IC}$ & 0 & 11 & 0 & 0 & 0 & 0 & 11 \\
\hline $\mathrm{MC}$ & 1 & 0 & 63 & 0 & 0 & 0 & 64 \\
\hline RV & 1 & 0 & 0 & 8 & 0 & 0 & 9 \\
\hline SHL & 0 & 0 & 0 & 0 & 30 & 0 & 30 \\
\hline $\mathrm{U}$ & 0 & 0 & 0 & 0 & 0 & 9 & 9 \\
\hline Column total & 11 & 11 & 63 & 10 & 33 & 9 & 137 \\
\hline
\end{tabular}

Where: $\mathrm{F}=$ Forest, $\mathrm{IC}=$ Intensively cultivated land, $\mathrm{MC}=$ Moderately cultivated land, $\mathrm{RV}=$ Riparian vegetation, $\mathrm{SHR}=$ Shrub land, and $\mathrm{U}=$ Urban area

$\mathbf{K}=\frac{\text { Total } *(\text { sum of correct })-\text { the sum of }(\text { Row total } * \text { column total })}{\text { Total squar }- \text { Row total } * \text { column total }}$

$K=\frac{137(9+11+63+8+30+9)-14 * 11+11 * 11+63 * 64+10 * 9+33 * 30+9 * 9}{1372-14 * 11+11 * 11+63 * 64+10 * 9+33 * 30+9 * 9}=0.92$

The kappa coefficient lies typically on a scale between 0 and 1 .Where, the latter indicates complete agreement and is often multiplied by 100 to give percentage measure of classification accuracy. Kappa value is characterized into three grouping: value greater than 0.8 represents strong agreement, 0.4-0.8 represents moderate agreement and that of less than 0.4 is considered as poor agreement (Congleton, 1991). Hence, in this study, the classification was accurate and is feasible for further application.

\subsubsection{Conservation Practice Factor (P-factor)}

The data related to management or support practice situations of the study watershed were collected during the field work through different techniques. The techniques employed includes interview of the local community, site observation by transect walk and secondary information collected from woreda and local agricultural offices. Therefore, values for this factor were assigned considering local management practices and based on values suggested by Hurni (1985). Management factors were obtained by assessing the different supporting practices in the study watershed and it was taken the weighted value for similar land use types.

\subsubsection{Generation of Parameter Values of Catchment Morphology}

Satellite remote sensing was used to generate morphological characterization of the catchment. Remote sensing technology is also important to generate the mapping and monitoring of the shifting of catchment stream line, river bank and erosion or deposition.

\subsection{Quantitative Analysis of Catchment Morphology}

Important morphological characteristics of a watershed include drainage density, form factor, elongation ratio and circulatory ratio, over land flow, bifurcation ratio, form factor and drainage texture. The relationship between the morphology of streams and the effect of erosion has been considered important for the assessment of erosion vulnerability in the watershed.

\subsubsection{Drainage Density}

Drainage density represents a relative higher number of streams per unit area and thus in this study. It was computed as the ratio of the total length of streams within a watershed to the area of the watershed. The drainage density of the watershed was determined by using the formula given below (Horton, 1932) whereas the total length of the stream and watershed area was determined by using Arc-GIS 10.2.

$\mathbf{D}=\frac{\mathbf{L}_{\mathbf{u}}}{\mathbf{A}}$

Where: $\mathrm{A}=$ area of the basin in $\left(\mathrm{km}^{2}\right)$, and $\mathrm{L}_{\mathrm{u}}=$ total stream length of order $\mathrm{u}$

\subsubsection{Circulatory Ratio}

The circulatory ratio is one factor that facilitate to soil erosion. The circulatory ratio of the watershed was estimated by taking the ratio of the area of the watershed to the area of the circle having the same perimeter as that of the watershed area. The circulatory ratio of the catchment was determined using the equation below (Schumn, 1956). The area of the circle having the same perimeter was determined using the following equation manually.

$\mathbf{R}_{\mathbf{c}}=\frac{\mathbf{4 A \pi}}{\mathbf{P}^{2}}$

Where: $\mathrm{A}=$ area of the basin in $\left(\mathrm{km}^{2}\right), \pi$ value i.e. 3.14 , and $\mathrm{P}=$ Perimeter of the basin in $(\mathrm{km})$

\subsubsection{Elongation Ratio}

The elongation ratio depicts that how much the watershed is long. The elongation ratio of the watershed was calculated as the ratio of the area of the basin to the maximum length of the watershed (equation 10). The maximum length of the watershed was determined by Arc-GIS 10.2 and the area of the basin determined in GIS environment during watershed delineation (Schumn, 1956). 
$\mathbf{R}_{\mathbf{e}}=\frac{\mathbf{2}}{\mathbf{L}_{\mathbf{b}}} *\left(\frac{\mathbf{A}}{\mathbf{P i}}\right) \mathbf{2}$

Where: $\mathrm{A}=$ Area of the basin, Pi value i.e. 3.14, and $\mathrm{L}_{\mathrm{b}}=$ basin length

\subsubsection{Form Factor}

The form factor of the watershed was determined using the area of the watershed and the square of the basin length of the area of the watershed which was in turn determined in Arc-GIS 10.2 environments. The basin length of the watershed was determined using the following formula (Horton, 1932).

$$
\mathbf{R}_{\mathbf{f}}=\frac{\mathbf{A}}{\mathbf{L}_{\mathbf{b}}{ }^{2}}
$$

Where: $\mathrm{A}=$ Area of the watershed, and $\mathrm{L}_{\mathrm{b}}=$ Watershed length

\subsubsection{Bifurcation Ratio}

Bifurcation ratio expresses the ratio of primary stream order to that of secondary stream order or secondary stream to that of tertiary stream order and so on. These catchment morphology parameter were determined by the equation given below (Schumn, 1956) where as the steam orders were determined in the Arc-GIS environment.

$\mathbf{R}_{\mathbf{b}}=\frac{\mathrm{Nu}}{\mathbf{N}_{\mathbf{u}+1}}$

Where: $\mathrm{N}_{\mathrm{u}}=$ total quantity of stream segments of order $\mathrm{u}$, and $\mathrm{N}_{\mathrm{u}+1}=$ number of segment of the next higher order in the watershed.

\subsubsection{Length of Overland Flow}

It is the length of water flow over the ground before it concentrated in to definite stream channel. This factor relates inversely to the average slope of the channel and quite similar with the length of sheet flow to large degree. This parameter was determined by the equation given below (Horton, 1945).

$\mathbf{L}=\frac{1}{\mathbf{D}^{2}}$

\subsubsection{Drainage Texture}

The drainage texture of the watershed is the ratio of the total number of stream to the perimeter of the watershed. The drainage texture was determined using the equation given below (Horton. 1945). The total number of the stream and the perimeter of the watershed were determined in Arc-GIS 10.2 environment.

$\mathbf{R}_{\mathbf{t}}=\frac{\mathbf{N}_{\mathbf{u}}}{\mathbf{P}}$

Where: $\mathrm{P}=$ Perimeter of the basin in $(\mathrm{km})$, and $\mathrm{N}_{\mathrm{u}}=$ total number of stream segments of order $\mathrm{u}$ in watershed.

\section{Result and Discussion}

\subsection{Rainfall Erosivity Factors}

The rainfall Erosivity factor ( $\mathrm{R}$ in Equation 1) was found to be in ranges from 533.6to $738.6 \mathrm{~mm}$. The R-factor value of the watershed, as show in the figure below was found to be high at the high altitude and low at the low altitude and corresponded to the rainfall distribution and amount. The rainfall data of six stations in the study area were used to interpolate by inverse distance weight method (IDW) in order to determine the Erosivity of rainfall of each grid cell. The upstream part of the watershed has high Erosivity as the precipitation rate is high in these parts of the watershed. The downstream part of the watershed showed lower Erosivity factor value that corresponds with the lower precipitation. 


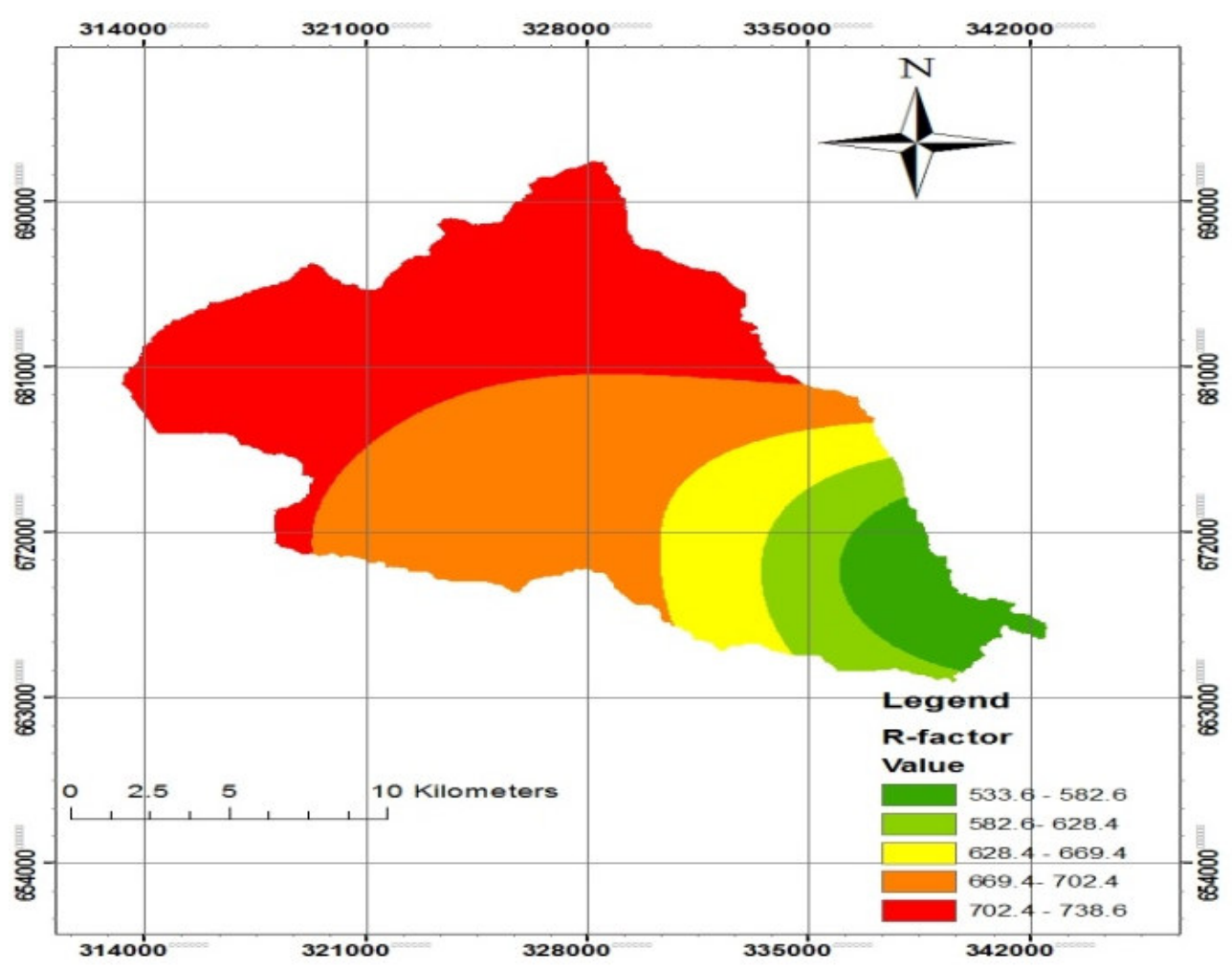

Figure 2: Rainfall Erosivity (R) factor variation in the watershed

\subsection{Soil Erodibility factor}

Kulfo watershed contains six dissimilar soil types that have similar Erodibility value (Table 3). The K-value was assigned based on FAO (1986). K-value of 0.1 was assigned for dystric fluvisols and leptosols. 0.15 was assigned for orthic acrisols, dystric nitisols, eutric fluvisols and Eutric nitisols and 0.2 was assigned for chromic vertisols. Therefore, the result indicated that $87.43 \%$ of the watershed area has Erodibility factor of 0.15 and the remaining $12.57 \%$ has the $\mathrm{K}$ value of 0.1 and 0.2 as shown in (Table 3 ) below. The above soils are highly affected by erosion. The magnitude and the spatial pattern of soil Erodibility factor are shown in (Figure 5) and it ranged between 0.1 at the upper and central part of the watershed and 0.2 in the lower part of the watershed. The largest part of the watershed area has the Erodibility factor value of 0.15 . Therefore, the soil that has Erodibility factor value of 0.15 is influential for sediment yield of the watershed. 


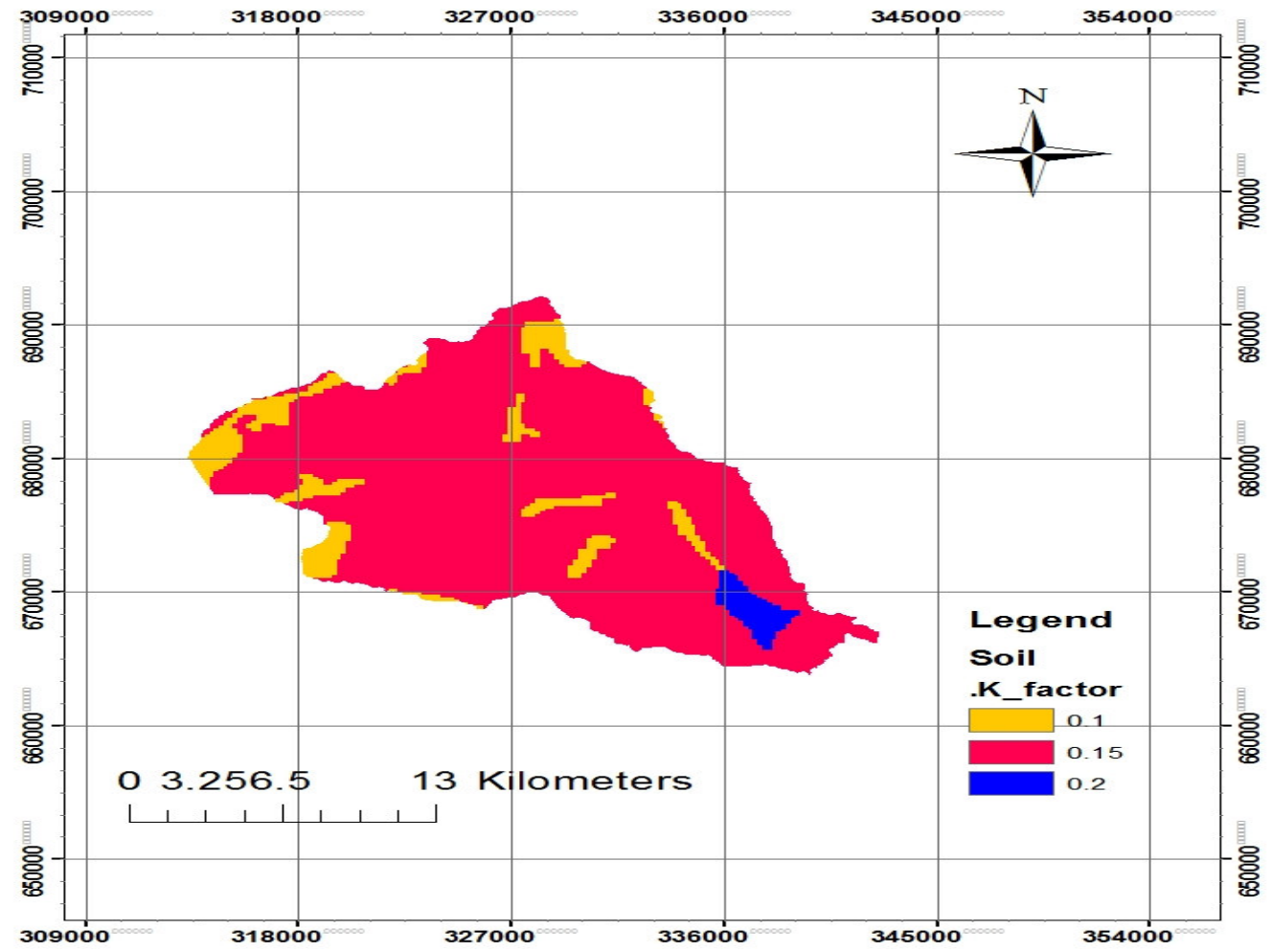

Figure 3: Soil Erodibility factor of the watershed

Table 2: Soil Erodibility factor value of soil classes of the watershed

\begin{tabular}{|c|c|c|c|c|}
\hline No & Soil class & $\begin{array}{l}\text { Area } \\
\left(\mathrm{km}^{2}\right)\end{array}$ & Area & K_factor \\
\hline 1 & orthic acrisols & 266 & 66.83 & 0.15 \\
\hline 2 & dystric nitisols & 57 & 14.32 & 0.15 \\
\hline 3 & leptosols & 4 & 1.01 & 0.1 \\
\hline 4 & dystric fluvisols & 37 & 9.3 & 0.1 \\
\hline 5 & eutric fluvisols & 13 & 3.27 & 0.15 \\
\hline 6 & chromic vertisols & 9 & 2.26 & 0.2 \\
\hline 7 & eutric nitisols & 12 & 3.02 & 0.15 \\
\hline
\end{tabular}

3.3 Slope length and slope gradient factor (LS)

The topographic component of RUSLE model was computed using (Equation 2) suggested by Moor and Bruch (1985); Mitasova and Matias (1999); and Simms et al. (2003). As shown 6 in the figure below in the lower part of the watershed the slope length is high due to high flow accumulation. On the other hand slope inclination is high in the middle parts of the watershed. Hence the combined LS factor ranges from 0 to 20.74 on the upper and middle part of watershed respectively. This implies that the influence of the combined LS factor for soil erosion is significant in the upper parts of watershed. 
Table 3: Slop class of the watershed

\begin{tabular}{ccccc}
\hline No & Slope classes & Area km & Area (\%) & Description \\
\hline 1 & $<3$ & 4.47 & 1.12 & flat or almost flat \\
2 & $3-8$ & 24.13 & 6.06 & Gently sloping \\
3 & $8-15$ & 58.84 & 14.78 & sloping \\
4 & $15-30$ & 130.67 & 32.83 & moderately steep \\
5 & $30-50$ & 99.08 & 24.89 & steep \\
6 & $>50$ & 81.73 & 20.54 & very steep
\end{tabular}

Figure 6 represent the spatial pattern of LS factor of the watershed. The LS factor of entire area of the watershed was classified in to five categories based on the geometrical interval. The length and slope gradient factor (LS-factor) of the watershed ranged in between 0 to 20.74. In the watershed, the lower part of the watershed showed the lower slope gradient whereas the upper part of the watershed has high gradient.

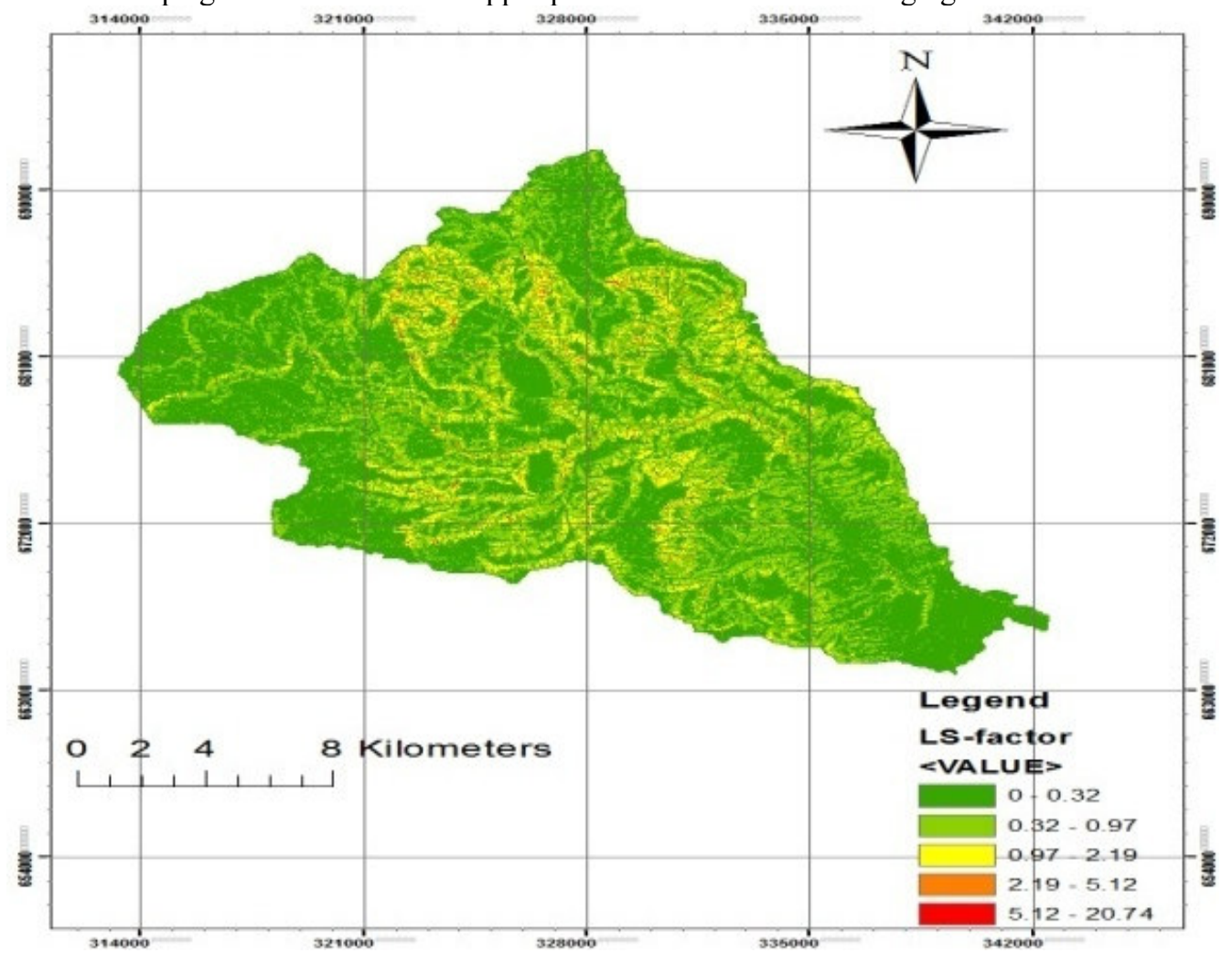

Figure 6: LS factor value distribution in the watershed.

\subsection{Land management factor $\left(C_{-}\right.$factor $)$}

The supervised image classification has showed that large portion of the watershed $(67.47 \%)$ is covered by cultivated lands. By the image classification of the study area, six land use and land cover classes were identified (moderately cultivated, intensively cultivated, Shrub land and bush, Forest, Urban area and Riparian vegetation). Maize and wheat were found to be the main dominant crop covers in the cultivated lands. Most of the upper catchment is agricultural land. Therefore these agricultural lands have higher value of $\mathrm{C}$ factor and are susceptible to erosion.

Table 4: Land cover land use and the corresponding value of C-factor of the watershed

\begin{tabular}{ccccc}
\hline No & Land use/cover class & Area in $\left(\mathrm{km}^{2}\right)$ & Area (\%) & C- factor \\
\hline 1 & Moderately cultivated & 268.19 & 67.38 & 0.15 \\
2 & Intensively cultivated & 1.58 & 0.4 & 0.15 \\
3 & Shrub land and bush & 113.92 & 28.62 & 0.02 \\
4 & Forest & 0.18 & 0.05 & 0.01 \\
5 & Urban area & 10.7 & 2.69 & 0 \\
6 & Riparian vegetation & 0.15 & 0.04 & 0.01 \\
\hline
\end{tabular}

The result of land use land cover classification showed most of the watershed $(67.38 \%)$ covered by moderately cultivated agricultural land and $(0.40 \%)$ intensively cultivated agricultural land (non fallow). Dense 
forest and riparian vegetation were identified in the outlet part of the watershed with the coverage area of $0.05 \%$ and 0.04 respectively. The magnitude and spatial pattern of land management /cover factor (C-factor) show values between 0 to 0.15 in (See Table 5). The C-factor of watershed values were assigned to be 0 for the areas representing well protected urban areas where no erosion process occurs (well protected) and 0.15 for the agricultural land. The $\mathrm{C}$ factor value of forest was assigned to be 0.01 . The land management/ cover factor (Cfactor) is dimensionless number ranging in between 0 to 1 that represents the degree of protection from erosion provided by vegetation.

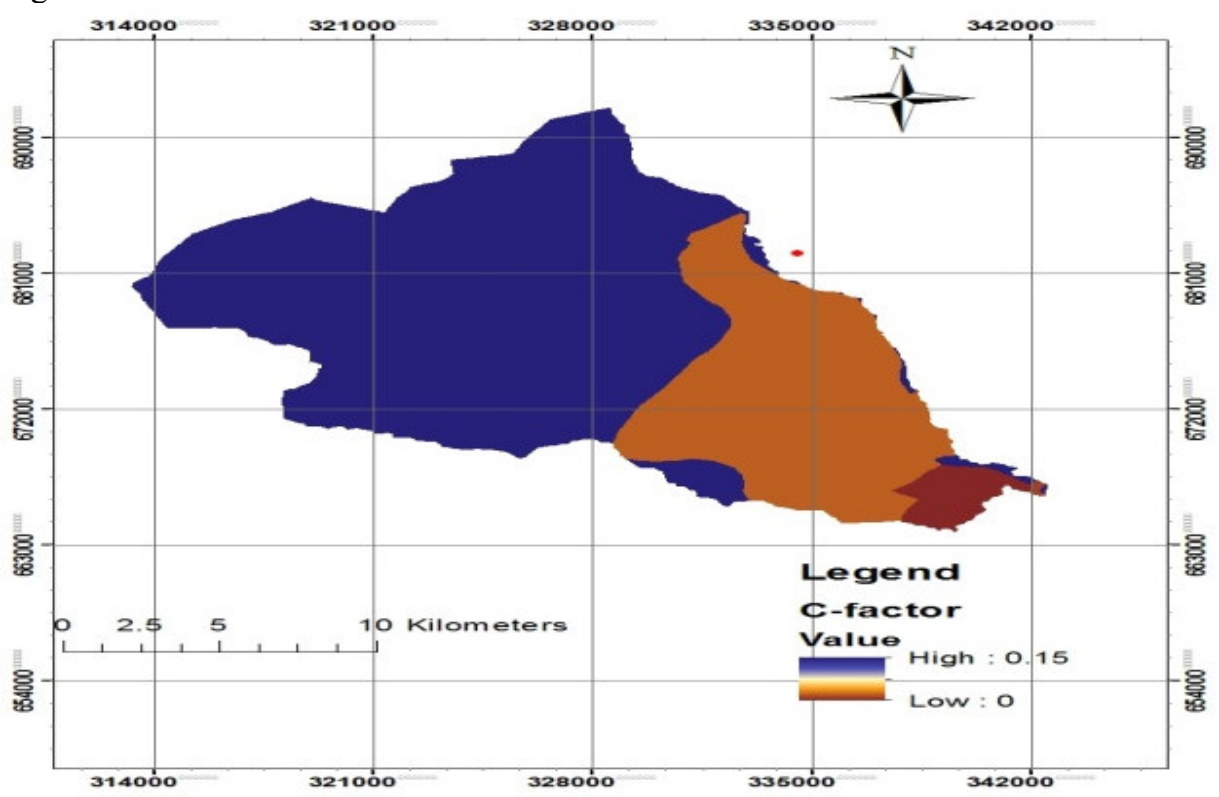

Figure 7: Land management/ cover factor of the watershed

\subsection{Support practice factor (P-Factor)}

The report of Arbaminch Zuria Woreda office of agriculture confirmed that various support practice and cropland in the study watershed were conducted. These include contour tillage, tracing, stream bank stabilization and strip cropping. Therefore in the study watershed the agricultural land were assigned $\mathrm{P}$ value on the basis of their slope class where as the $\mathrm{P}$ value of 1 was assigned for other land uses/cover classes.

Table 5: $\mathrm{P}$ value (Wischemeier and Smith, 1978)

\begin{tabular}{ccc}
\hline land use type & slope $\%$ & P factor \\
\hline agricultural land & $0-5$ & 0.1 \\
& $50-10$ & 0.12 \\
$10-20$. & 0.14 \\
& $20-30$. & 0.19 \\
& $30-50$. & 0.25 \\
other land cover & $50-100$ & 0.33 \\
\hline
\end{tabular}

The P-factor of watershed value decrease by adopting the different conservation practice. In the study area the support practice factor applied on the middle and low parts of the watershed. These indicates that the lower $p$ factor value have better practice for controlling soil erosion. The P-factor value of the study area watershed ranged from 0.55 to 1 . 


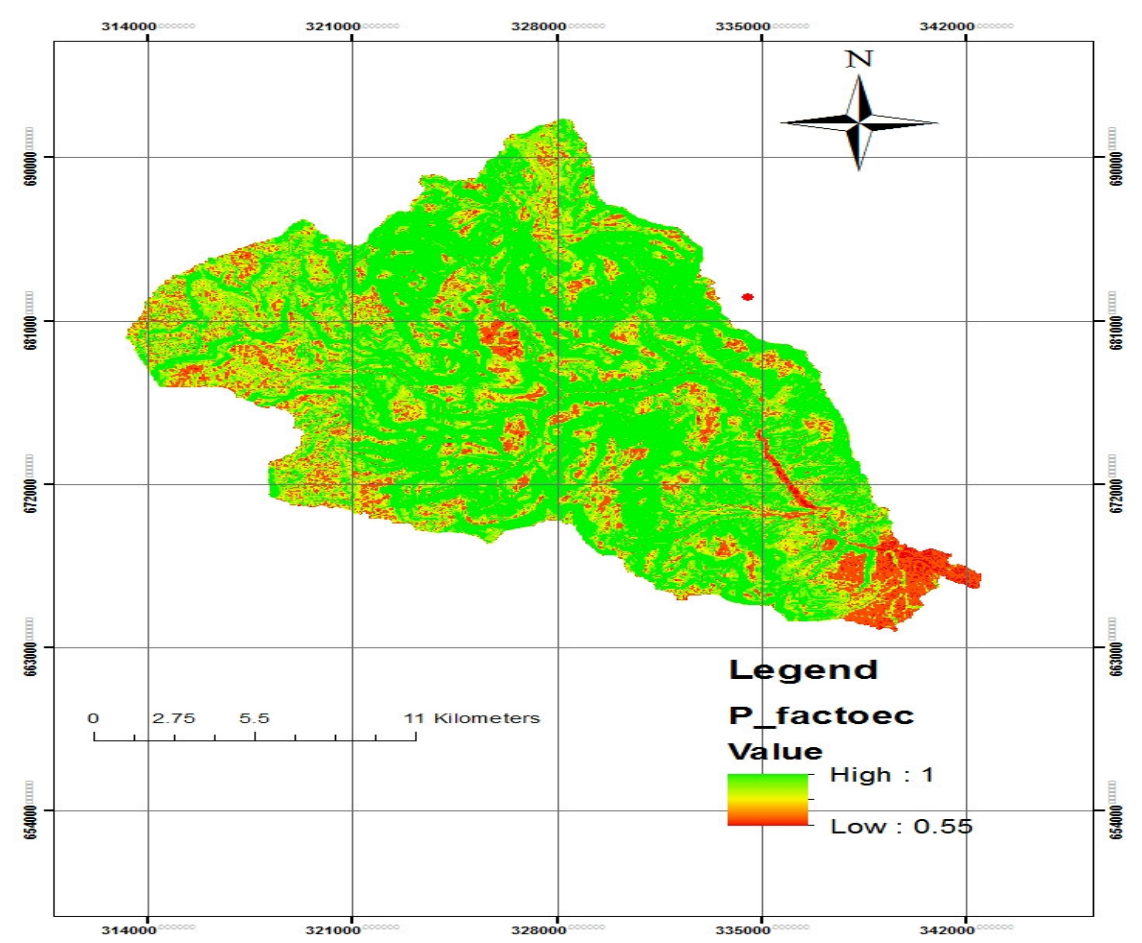

Figure 4: Supporting practice factor (P- factor) of the watershed

\subsection{Amount of Soil loss per unit area per year}

Based on the analysis, the estimated soil loss result showed that the extent of soil loss from the watershed ranged from 0.00 to10713.5 tons ha ${ }^{-1}$ year $^{-1}$. The mean annual soil loss was 88.5 tons $\mathrm{ha}^{-1} \mathrm{year}^{-1}$; which is much greater than the tolerable soil loss level $10 \mathrm{t} \mathrm{ha}^{-1} \mathrm{year}^{-1}$ (Hurni, 1985).The result of study falls within the ranges of the findings of FAO (1984). According to the estimate of FAO (1984) the annual soil loss of the highlands of Ethiopia ranged from 16 to 300 tons ha $^{-1}$ year $^{-1}$ of pasture, ranges and cultivated fields throughout Ethiopia. The distribution of soil loss in the watershed has been showed in the figure 13 below. The erosion map has been generated by superimposed RUSLE factor map.

The result showed that the mean annual soil loss of the watershed range from none significant $(0$ tons ha${ }^{1}$ year $\left.{ }^{-1}\right)$ to highly sever $\left(253.38\right.$ tons ha $^{-1}$ year $\left.^{-1}\right)$ soil erosion rate. The mean annual soil loss of the whole watershed area was 88.57 tons ha $^{-1}$ year ${ }^{-1}$. The total annual soil loss from the watershed was found to be 3,862,077 tons/year from 39900 ha of land. Most of soil erosion affected areas are spatially situated in the upper steepest slope part and middle part of the watershed. These areas also include the areas of acrisols with high soil Erodibility character $(0.15)$ values and agricultural lands. 


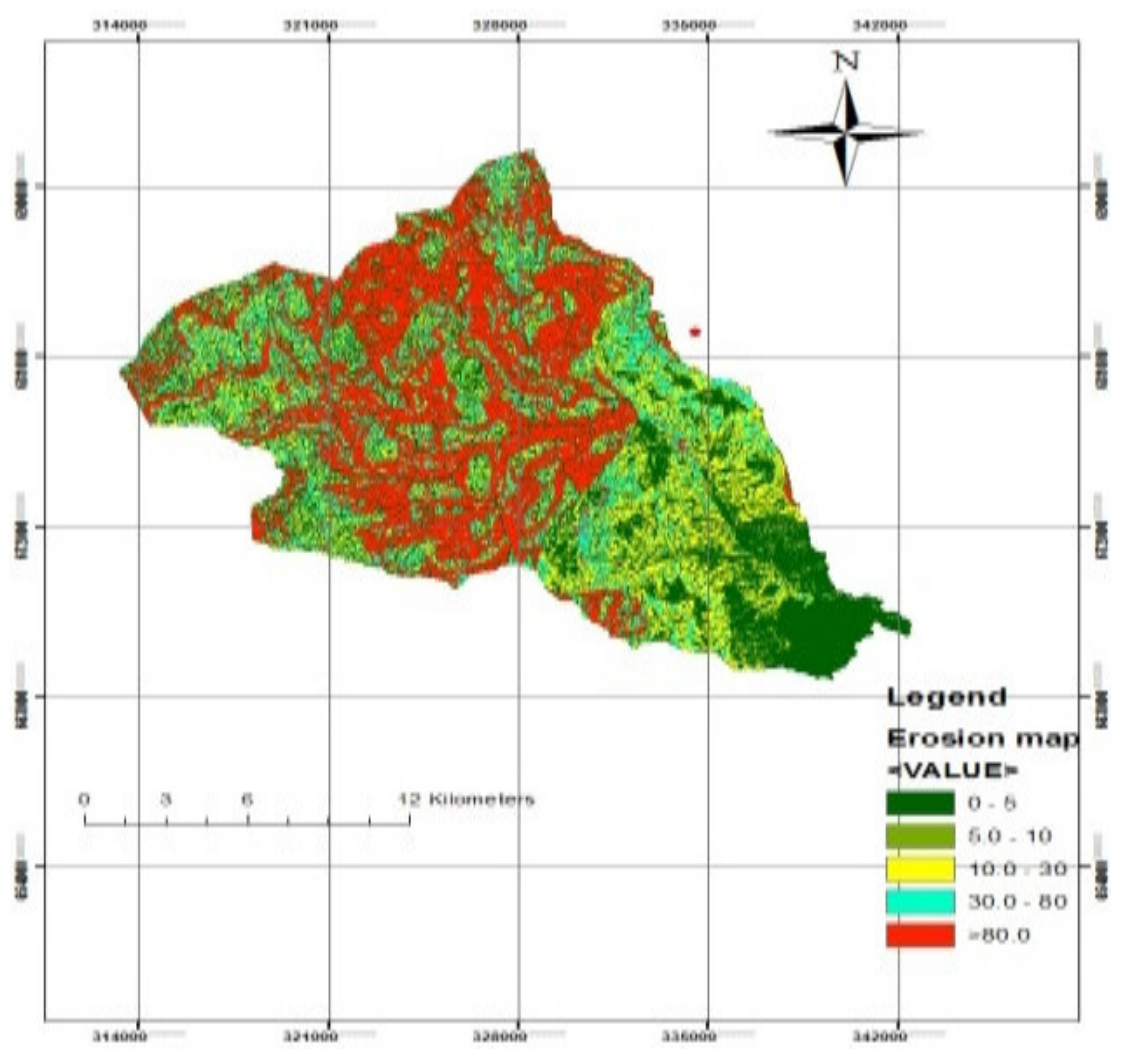

Figure 5: Spatial pattern of the soil loss from the watershed

\subsection{Prioritization of Sub-watersheds Based on erosion spot area}

In identifying and implementing conservation measures for different sub watershed. Prioritization of sub watershed was done on the basis of average annual soil loss. Estimated value of sub watershed soil loss was classified on the basis of mean annual soil loss. Prioritization of different erosion classes followed the FAO basic classification of desertification FAO (1986) with some modification to suit the features of the study area (See Table 9). Soil loss tolerance (SLT) depicts the maximum allowable soil loss that will maintain an economic and a high level of productivity (Wischmeier\& Smith. 1978; Gebreyesus \& Kirubel, 2009; FAO, 1984). The normal SLT values range from 5 to 10 tons ha $^{-1}$ year $^{-1}$ (Renard et al., 1996). The assignment of a range depended on the judgment of how much erosion would be harmful to the soil. Figure10 shows areas with higher soil loss potential than the SLT. Table 6: Severity class and prioritization of sub watershed

\begin{tabular}{|c|c|c|c|c|c|}
\hline SWS & Erosion risk class & $\begin{array}{c}\text { priority } \\
\text { class }\end{array}$ & $\begin{array}{c}\text { severity } \\
\text { class }\end{array}$ & $\begin{array}{c}\text { Area in } \\
\mathrm{km}^{2}\end{array}$ & Area $(\%)$ \\
\hline (SW19) & $0-5$ & 5 & Minimal & 33.92 & 8.27 \\
\hline$(\mathrm{SW} 17)$ & $5-10$ & 4 & Low & 16.12 & 3.93 \\
\hline$(\mathrm{SW} 16, \mathrm{SW} 15)$ & $10-30$. & 3 & Moderate & 66.63 & 16.3 \\
\hline (SW3,SW4,SW7,SW18) & $30-80$ & 2 & High & 69.32 & 16.9 \\
\hline $\begin{array}{l}\text { (SW1, SW2,SW5,SW6,SW8, } \\
\text { SW9, ,SW12,SW13,SW14 } \\
\text { SW10,SW11,) }\end{array}$ & $>80$ & 1 & Extreme & 224.61 & 54.8 \\
\hline
\end{tabular}

As shown in the table 9soil loss risk classes of study area extreme and high soil loss covers more percentage $(71.7 \%)$ from the entire watershed area. most of these erosion risk area are spatially situated in the upper and middle part of watershed. Since, the topography of the watershed has been very steep, and most of upper catchment is agricultural land and have been high erodible soil character. The estimated soil loss rate and the spatial pattern are generally realistic, due to what has been observed in the field and natural characteristic of the watershed (land escape and soil) and also majority of the study area have cultivated land use. Therefore these areas needs immediate soil and water conservation work to prevent erosion loss. Figure 14 shown that the spatial distribution of severity class of the watershed. Based on classification of severity classes most of the watershed area are fall under extreme condition. 


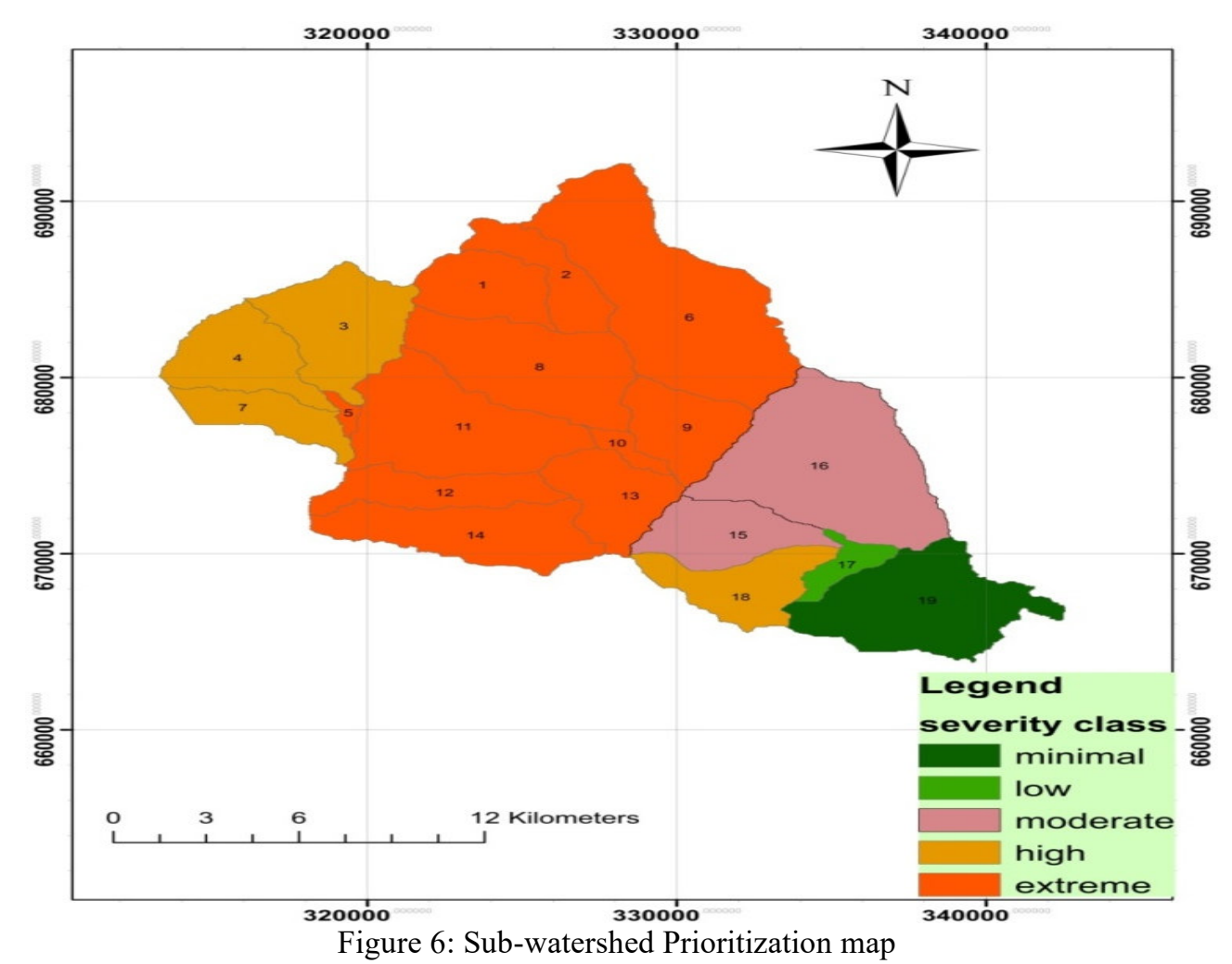

Figure 14 also shows that the spatial distribution of the erosion severity class. Extreme soil erosion severity class has more percentage in area coverage. The extreme severity classes located on the upper steep watershed part and the lower part of the watershed has minimal erosion severity classes. Since, these parts of the watershed have better protection and flat topography.

\section{Conclusion and Recommendation \\ 4.1 Conclusion}

The total amount of soil loss from the watershed is about 3.862.077 tons per year from a total area of 39900 hectare. The mean annual soil loss from each sub-watershed ranged from 4.46 to 253.38 tons ha $^{-1} \mathrm{year}^{-1}$. The 11 subwatersheds (SWS1,SWS10, SWS9,SWS2,SWS8,SWS13,SWS12 SWS11,SWS14,SWS6 and SWS5) were predicted to experience annual soil loss of more than the watershed average ( 88.8 tons ha $^{-1}$ year-1) whereas 8 subwatershed (SWS3,SWS4,SWS7, SWS18,SWS15,SWS16,SWS17 and SWS19) estimated to experience mean annual soil loss less than the watershed average. The result showed that eleven (11) sub-watersheds (SW1, SW2, SW5, SW6 SW8, SW9, SW10, SW11, SW12, SW13 and \& SW14) fell under extreme soil erosion classes $(>80$ tons ha ${ }^{-1}$ year $^{-1}$ ) covering an area of 22461 hactare $(54.8 \%)$ which contributed $31.27 \%$ of the total soil loss. Whereas four (SW 3, SW4, SW7\& SW18) fell under high soil erosion classes $\left(30-80\right.$ tons ha $^{-1}$ year $\left.{ }^{-1}\right)$ covering an area of $16.9 \%$ and contributed $26.78 \%$ of the total soil loss. The SW15, SW16, SW17 and SW19 that are predicted to experience low to moderate soil loss together cover about $52.5 \%$ of the watershed area and contribute $41.95 \%$ of the total soil loss.

\subsection{Recommendation}

1. Further studies will be recommended to decide what conservation structure will be required for each severity classes of the watershed.

2. The local communities should take immediate soil conservation measures in their cultivated lands by applying different soil protective methods like mulching, trip cropping, Terracing, contour plowing, multiple cropping and other indigenous means of soil conservation techniques

3. The output of the study indicates that the sub-watersheds which have affected by very high and high severity classes need immediate attention in their order of soil erosion potential.

4. For the better estimation of rainfall Erosivity dense rainfall station needed in the watershed.

5. Even though, GIS, RS and Multi-Criteria Evaluation model is a valuable tool for the quantifications and mapping of an estimated value of soil loss at various locations, further studies in limited spatial scale of watershed using high resolution data is recommended to monitor and mitigate the watershed properly. 


\section{Authors' agreement}

Based on the requirement that 'Authors should disclose all financial or relevant interest that may have influenced the study', we the under listed authors wish to say that there is no conflict among us concerning all arrangements about this paper. Hence, we look forward for it to be published as early as possible.

\section{Reference}

FAO, (1984). "Degradation Processes in the Ethiopian highlands their Impacts and Hazards". Food and Agriculture Organization. Rome.

FAO, (1986). "Ethiopian Highland Reclamation Study: Report prepared for the government of Ethiopia". Rome .Vol.I

Gebreyesus.B. and Kirubel.M. (2009). "Estimating Soil Loss Using Universal Soil Loss Equation (USLE) for Soil Conservation planning at Medego Watershed, Northern Ethiopia”. Journal of American Science 2009,5,5869.

Helden, U.(1987). “An assessment of woody biomass. Community forests. Land use and soil erosion in Ethiopia”. Lund. Lund University Press.

Horton, RE. (1932). "Drainage basin characteristics”. Journal of Trans-America Geophysics Union, 13,350-361.

Horton, R.E. (1945). "Erosional development of streams and their drainage basins. hydrophysical approach to quantitative morphology". Journal of Geological Society of America, 56, 275-370.

Hurni, H. (1985). "Erosion-Productivity Conservation Systems in Ethiopia". 4th ISCO Conference.Venezuala.654-674.

Mitasova, H. and Mitas, Z. (1999). "Modeling soil detachment with RUSLE 3D using GIS". IL. USA: University of Illinois at Urbana-Champaign.

Morgan, R. (1994). "Soil Erosion and Conservation”. Silsoe College. Cranfield University. Cranfield

Moore, I. D. and Bruch, G. J. (1985). "Physical basis of the length-slope factor in the universal soil loss equation". Journal of Soilless Science of American Journal,50, 1294-1298.

Scholes, RJ. Skole, D. Ingram, JS. (1995). "A global data base of soil properties: proposal for implementation". IGBP-DIS working paper No.10.University of Paris. France.

Shi, Z.H. Cai, C.F. Ding, S.W. Wang, T.W and Chow, T.L.(2003). "Soil conservation planning at the small watershed level using RUSLE with GIS: a case study in the three Gorge Area of China". Journal of Catena, $55,33-48$.

Renard, K.G. Foster, G.R. Weesies, G.A. McCool, D.K. and Yoder, D.C. (1996). "Predicting Soil Erosion by Water: A Guide to Conservation Planning with the Revised Universal Soil Loss Equation (RUSLE)". USDA. Washington. DC.

Renard, K.G. Foster, G.R. Weesies, G.A. McCool, D.K and Yoder, D.C. (1997). "Predicting soil erosion by water a guide to conservation planning with the Revised Universal Soil Loss Equation (RUSLE)". Agriculture Hand book No.703.Agricultural Research Service. Washington. DC.

Saavedra, C. (2005). "Estimating spatial patterns of soil erosion and deposition in the Andean region using geo-information techniques": a case study in Cochabamba. Bolivia Ph.D.dissertation.Wageningen University. The Netherlands

Schumm, SA. (1956). "Evolution of drainage systems and slopes in badland at Perth Amboy”. New Jersey. Journal of Bull Geological Society America, 67,597-646

Simms, A. D. Woodroffe, C. D. and Jones, B. G. (2003). "Application of RUSLE for erosion management in a coastal catchment". Southern NSW. In Proceedings of the international congress on modeling and simulation: integrative modeling of biophysical, social and economic systems for resource management solutions (pp. 678-683). Townsville. Australia.

Wischmeier, W.H. and Smith.D.D. (1978). "Predicting rainfall erosion losses". A guide to conservation planning.Agric.HandB.No.537.US Department of Agriculture. Washington. DC. 